\title{
SERUM HOMOCYSTEINE LEVELS IN PATIENTS WITH RETINAL VEIN OCCLUSION: A MODIFIABLE RISK FACTOR
}

\author{
Devendra Saxena ${ }^{1}$
}

${ }^{1}$ Associate Professor, Department of Ophthalmology, Pramukhswami Medical College.

\begin{tabular}{l}
\hline ABSTRACT \\
\hline OBJECTIVE \\
To find association of raised serum homocysteine levels in patients with retinal vein occlusion. \\
METHODS \\
25 patients with recent retinal vein occlusion who presented at Retina Clinic from 2012 to 2013 with followup up to 2015 \\
underwent Serum Homocysteine Level analysis by liquid chromatography.
\end{tabular}

\section{RESULTS}

Out of 25 patients of retinal vein occlusion, 18 patients (72\%) had raised serum homocysteine levels and 7 (28\%) had normal levels. Of 25 patients, 14 were male and 11 female showing no significant gender dominance; 15 patients had BRVO with 12 involving superotemporal, 3 involving inferotemporal arcade. Ten patients had CRVO.

\section{CONCLUSION}

Patients with raised serum homocysteine levels have higher risk of retinal vein occlusion. It may serve as the only modifiable risk factor for preventing further damage in same eye and future involvement in other eye by maintaining normal serum homocysteine levels.

\section{KEYWORDS}

Retinal Vein Occlusion, Serum Homocysteine.

HOW TO CITE THIS ARTICLE: Saxena D. Serum homocysteine levels in patients with retinal vein occlusion: a modifiable risk factor. J. Evolution Med. Dent. Sci. 2016;5(30):1557-1558, DOI: 10.14260/jemds/2016/366

\section{INTRODUCTION}

Elevated serum homocysteine level has recently been shown as modifiable risk factor for retinal vein occlusion, control of which can prevent further risk of venous occlusion in same eye and involvement of other eye. $(1,2,3)$

Homocysteine is a metabolic product of methionine metabolism. It can be converted back to methionine or by trans-sulfuration converted to cysteine.

The metabolism of the amino acid homocysteine consists of a vitamin B6-dependent trans-sulfuration pathway involving the enzyme Cystathionine $\beta$-Synthase (CBS) and a folate- and vitamin B12-dependent remethylation pathway involving the enzymes Methylene Tetrahydrofolate Reductase (MTHFR) and methionine synthase deficiencies. C677T gene polymorphism, is the most common mutation in the gene that codes for the MTHFR enzyme. This single-point mutation (C677T) in the coding region for the MTHFR binding site (exon 4) is autosomal recessive, leads to the substitution of a valine for an alanine and results in a thermolabile variant of the MTHFR (tlMTHFR). ${ }^{(4,5)}$ Acquired hyperhomocysteinemia in the absence of any mutation or polymorphism may be caused by folate deficiency, vitamins B6 and B12 deficiencies, renal

Financial or Other, Competing Interest: None.

Submission 22-02-2016, Peer Review 19-03-2016,

Acceptance 24-03-2016, Published 14-04-2016.

Corresponding Author:

Dr. Devendra Saxena,

Associate Professor

Vitreo-Retinal Consultant,

Department of Ophthalmology,

PSMC, Karamsad-388325,

Anand Gujarat.

E-mail: deekaysaxena@yahoo.com

DOI: $10.14260 /$ jemds $/ 2016 / 366$ failure, diabetes mellitus, hypothyroidism, carcinoma, pernicious anaemia, inflammatory bowel disease and methotrexate, theophylline or phenytoin therapy.(6)

There is strong inverse correlation of plasma homocysteine with plasma folate concentration.(7,8) In contrast to folate serum, B6/B12 levels show only a weak correlation with plasma homocysteine.

Homocysteine contributes to vascular injury by causing endothelial cell damage followed by platelet aggregation and thrombus formation. Increased thrombogenicity is also mediated by release of platelet-derived growth factor. $(9,10)$

\section{MATERIALS AND METHODS}

All patients with recent retinal vein occlusion attending/referred to the Retinal Clinic from 2012 to 2013 were included in the study and followed for a period of 2 years till 2015.

Patients with other coexisting vascular retinopathies like vasculitis, diabetic retinopathy, Eales disease, pregnancyinduced hypertension, renal, hepatic or thyroid disease, chronic alcohol abuse and anticonvulsant therapy were not included in the study.

Fasting blood sample for the cases were taken and analysed by high performance liquid chromatography for serum homocysteine levels.

Normal serum homocysteine value is between $5-15$ $\mu \mathrm{mol} / \mathrm{L}$ in our laboratory.

\section{RESULTS}

- $\quad$ Out of 25 patients, 18 had increased level of serum homocysteine, while 7 patients had normal levels.

- 14 patients were male and 11 female, so showing no significant gender predilection. 
- 15 cases had BRVO, out of which 12 were superotemporal in location and 3 were inferotemporal.

- 10 patients had CRVO.

- $72 \%$ patients with RVO had raised serum homocysteine level in comparison to $28 \%$ with normal values. $(11,12,13)$

\section{DISCUSSION}

The relationship between serum homocysteine and other vascular diseases has well been documented. Our study supports this relationship for retinal vascular occlusion in Indian population. $(14,15)$

$72 \%$ patients with retinal vein occlusion had raised Serum Homocysteine level.(16)

In BRVO superotemporal arcade was involved in $80 \%$ of cases as compared to $63 \%$ in American population (AAO 2012-2013 section 12 page 121). It can be attributed to increased $\mathrm{AV}$ crossing junctions in superotemporal quadrant as compared to inferior one.

The aetiology of raised serum homocysteine is multifactorial. It is a metabolite of methionine. It can be converted back to methionine or to cysteine. If methionine is in excess than homocysteine is irreversibly converted to cysteine by cystathionine beta synthase with vitamin $\mathrm{B} 6$ as cofactor.

Homocysteine is remethylated via methionineconserving pathway. It requires folic acid and MTHFR (Methyl tetrahydrofolate reductase) enzyme for its conversion.

Deficiency of folic acid or mutation in MTHFR enzyme can result in raised serum homocysteine level.

Our patients received folic acid supplement $5 \mathrm{mg}$ once daily for three months initially and continued thereafter once levels were under normal limit.

Increased serum homocysteine levels lead to thromboembolic event by endothelial damage, platelet aggregation and thrombus formation leading to retinal vein occlusion.(17)

It needs a prolonged followup and larger sample size to establish the long-term benefit of lowering serum homocysteine level in patients with retinal vein occlusion to prevent recurrence in same eye and involvement of other eye.

\section{REFERENCES}

1. Vine AK. Hyperhomocysteinemia: a new risk factor for central retinal vein occlusion. Trans Am Ophthalmol Soc 2000;98:493-503.

2. Abu El-Asrar AM, Abdel Gader AG, Al-Amro SA, et al. Hyperhomocysteinemia and retinal vascular occlusive disease. Eur J Ophthalmol 2002;12(6):495-500.

3. Blondel J, Glacet-Bernard A, Bayani N, et al. Retinal vein occlusion and hyperhomocysteinemia. J Fr Ophtalmol 2003;26(3):249-53.
4. Weger $M$, Stanger 0 , Deutschmann $H$, et al. Hyperhomocyst(e)inemia and MTHFR C677T genotypes in patients with central retinal vein occlusion. Graefes Arch Clin Exp Ophthalmol 2002;240(4):286-90.

5. Di Crecchio L, Parodi MB, Sanguinetti G, et al. Hyperhomocysteinemia and the methylenetetrahydrofolate reductase $677 \mathrm{C}-\mathrm{T}$ mutation in patients under 50 years of age affected by central retinal vein occlusion. Ophthalmology 2004;111(5):940-5.

6. Gao W, Wang YS, Zhang P, et al. Hyperhomocysteinemia and low plasma folate as risk factors for central retinal vein occlusion: a case-control study in a Chinese population. Graefes Arch Clin Exp Ophthalmol 2006;244(10):1246-9.

7. Lowering blood homocysteine with folic acid based supplements: meta-analysis of randomised trials homocysteine lowering trialists' collaboration. BMJ 1998;316(7135):894-8.

8. Saricaoglu MS, Karakurt A, Sengun A, et al. Plasma homocysteine levels and vitamin B status in patients with pseudoexfoliation syndrome. Saudi Med J 2006;27(6):833-7.

9. Weger M, Stanger 0, Haas A. Hyperhomocysteinemia: a risk factor for central retinal vein occlusion. Am J Ophthalmol 2001;131(2):290-1.

10. Guba SC, Fonseca V, Fink LM. Hyperhomocysteinemia and thrombosis. Semin Thromb Hemost 1999;25(3):291-309.

11. Yaghoubi GH, Madarshahian F, Mosavi M. Hyperhomocysteinaemia: risk of retinal vascular occlusion. East Mediterr Health J 2004;10(4-5):633-9.

12. Chua B, Kifley A, Wong TY, et al. Homocysteine and retinal vein occlusion: a population-based study. Am J Ophthalmol 2005;139(1):181-2.

13. Brown BA, Marx JL, Ward TP, et al. Homocysteine: a risk factor for retinal venous occlusive disease. Ophthalmology 2002;109(2):287-90.

14. Cahill M, Karabatzaki M, Meleady R, et al. Raised plasma homocysteine as a risk factor for retinal vascular occlusive disease. Br J Ophthalmol 2000;84(2):154-7.

15. Moghimi $S$, Najmi $Z$, Faghihi $H$, et al. Hyperhomocysteinemia and central retinal vein occlusion in Iranian population. Int Ophthalmol Epub 2007 Jul 17, 2008;28(1):23-8.

16. Narayanasamy A, Subramaniam B, Karunakaran C, et al. Hyperhomocysteinemia and low methionine stress are risk factors for central retinal venous occlusion in an Indian population. Invest Ophthalmol Vis Sci 2007;48(4):1441-6.

17. Sottilotta G, Oriana V, Latella $C$, et al. Role of hyperhomocystinemia in retinal vascular occlusive disease. Clin Appl Thromb Hemost 2007;13(1):104-7. 